\title{
䅡椎に生じた特発性春䯣硬膜外血腫の経験
}

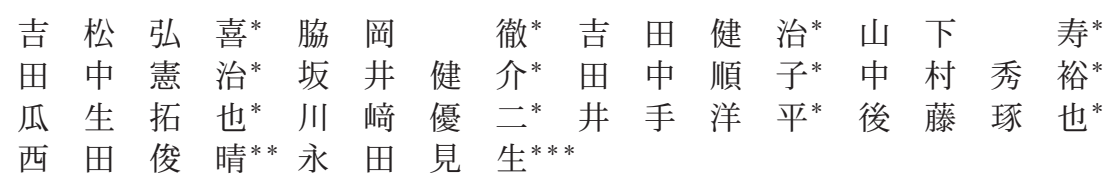

\section{Clinical Results of Spontaneous Spinal Epidural Hematoma in the Cervical Area}

\author{
Hiroki Yoshimatsu*, Toru Wakioka*, Kenji Yoshida*, \\ Hisashi Yamashita*, Kenji Tanaka*, Kensuke Sakai*, \\ Junko Tanaka*, Hidehiro Nakamura*, Takuya Uryu*, \\ Yuji Kawasaki*, Yohei Ide*, Takuya Goto*, \\ Toshiharu Nishida**, and Kensei Nagata***
}

頚椎発症の特発性脊髄硬膜外血腫 4 症例を経験したので報告する．痛みから麻痺出現までは平均 67 分 であった，発生部位は平均 6.8 椎間であり，全例硬膜外背側に位置していた。治療は保存療法を 2 例に, 手術を 2 例に施行し，全例改善した。 また, 頝椎発症のSSEH の自然回復例の調査では, 6 時間以内に改 善傾向を示す割合が高いことがわかった。攧椎発症の SSEH は麻痺の程度を考慮し，手術を検討しなが ら, 注意深く症状経過を観察する必要があると思われた.

We report four cases of spontaneous spinal epidural hematoma in the cervical area. The duration from pain to the appearance of paralysis was 67 minutes on average. The spinal epidural hematoma was located in 6.8 vertebral segments on average, and all existed in the posterior of the spinal cord. Two patients were treated non-operatively, while the other two patients were treated operatively. All four patients improved after the treatment. Moreover, it was found that the percentage of early symptom improvement within six hours from onset is high in this investigation on non-operative treatment for spontaneous spinal epidural hematoma in the cervical area. These results suggest that careful observations of symptoms are required for spontaneous spinal epidural hematoma in the cervical area while preparing for surgery giving consideration to neurological conditions.

Key words : spontaneous spinal epidural hematoma（特発性脊髄硬膜外血腫）, treatment（治療）, cervical myelopathy（頝䯣症）

\section{は じめに}

特発性脊䯣硬膜外血腫 (spontaneous spinal epidural hematoma : 以下 SSEH）は稀な疾患とさ れてきたが，MRI の普及により報告例は増加してい る.しかし，未だに一定の治療方針に対する見解は得 られていない. 今回, 頚椎発生の SSEH を経験した

ので報告する.

対象

当院にて頝椎発生の SSEH と診断された 4 例であ る。性別は男性 1 例，女性 3 例で，年齢 61 歳から 82 歳 (平均 72 歳) であった。基礎疾患として 3 例に高 血圧を，1例に $\mathrm{HD}, \mathrm{DM}$ を認めた.

\footnotetext{
* 聖マリア病院整形外科 Derpartment of Orthopaedic Surgery, St. Mary's Hospital, Fukuoka, Japan

** 社会保険田川病院 Derpartment of Orthopaedic Surgery, Social Insurance Tagawa Hospital, Fukuoka, Japan

*** 久留米大学整形外科 Derpartment of Orthopaedic Surgery, Kurume University, School of Medicine, Fukuoka, Japan
} 
結果

発症誘因を有するものは 2 例認めた. 痛みから麻痺 出現までは 30 分〜 2 時間（平均 67 分）であつた. 発 生部位は $5 \sim 8$ 椎間（平均 6.8 椎間）であり, 全例硬 膜外背側に位置していた. 治療は保存療法を 2 例に, 手術を 2 例に施行し, 全例改善した.

\section{症例}

症例 169 歳 女性. ソファーから起き上がり（頝 部前屈), 頚部痛出現. 徐々に両上下肢しびれ出現. 1 時間後, 四肢麻痺出現し，紹介搬入となつた。搬入 時, 頚部痛, 四肢の知覚低下 (C5 以下), 筋力低下 (MMT 3, 右下肢のみ MMT $0 \sim 1$ ), 深部腱反射低 下あり。頚椎 MRI にて C2-Th2 レベル硬膜外背側 に位置する不整形の $\mathrm{T} 1$ 強調像で等信号, T2 強調像 で高信号の血腫を認めた（図 1)。発症後 2.5 時間に て知覚・運動障害の改善傾向認めたため, 保存的治療 を選択した。発症後 12 時間にはほぼ症状改善してい た. 発症 2 年で症状なし.

症例 282 歳 男性. テレビを持ち上げた後より, 頚部～両肩痛出現. 30 分後, 四肢麻痺出現し, 搬入
となつた. 搬入時, 頚部〜両肩痛, 四肢の知覚低下, 筋力低下あり（上肢 MMT 3，下肢 MMT 2）。頝椎 MRI にて C2-C6 レベル硬膜外背側に位置する T1 強 調像で等信号, T2 強調像で高信号, 周囲が造影され る血腫を認めた. 発症後 1.5 時間にて知覚・運動障害 の改善傾向認めたため, 保存的治療を選択した. 発症 後 2 時間にはほぼ症状改善し, 発症 1 年 8 ケ月で再発 なし.

症例 369 歳 女性. 誘因なく頝部痛出現し, 2 時 間後，四肢麻痺出現，紹介搬入となつた．搬入時，後 頚部痛，四肢の知覚低下, 筋力低下 (MMT 上肢 3 , 下肢 $1 \sim 2)$, 下肢深部腱反射充進，尿閉あり。顼椎 MRI にて C3-C7 レベル硬膜外背側に位置する T1 強 調像で等信号，T2 強調像で高信号の血腫を認めた (図 2). 発症後 15 時間にて症状改善傾向なく, 手術 （血腫除去術，C3-C7 椎弓形成術）を行った. 術後 早期より症状改善傾向認め, 術後 2 日で著明な症状改 善あり. 術後 3 年で軽度の頚部こわり感のみ残存した.

症例 461 歳 女性. 誘因なく頚部痛出現. 1 時間 後, 四肢麻痺出現し，紹介搬入となつた．搬入時，四 肢の知覚低下 (C4 以下), 筋力低下 (MMT 左上下肢 $0 \sim 1$, 右上下肢 3$)$, 深部腱反射低下, 肛門括約筋反

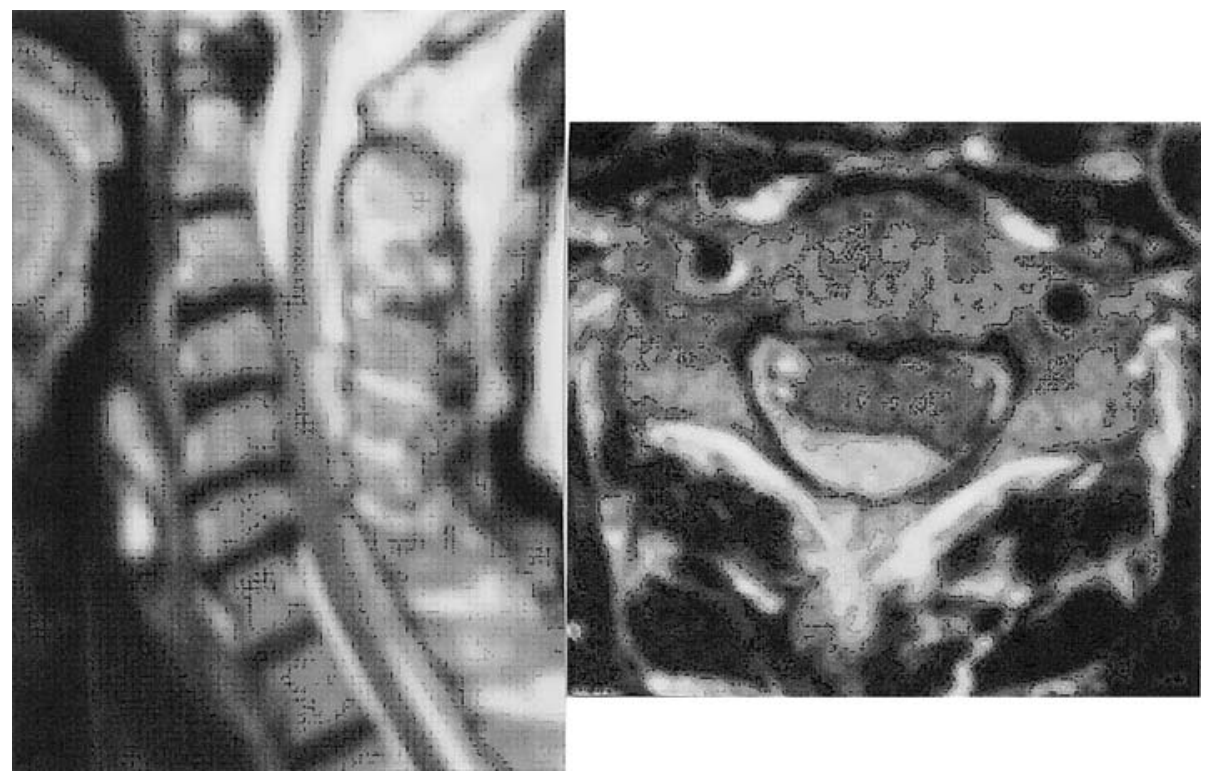

図 1 症例 1 発症後 2 時間 : T2 強調画像 $\mathrm{C} 2$ - Th2 レベル硬膜外背側に位置する不整 形の T1 強調像で等信号, T2 強調像で高信号の血腫を認めた。 


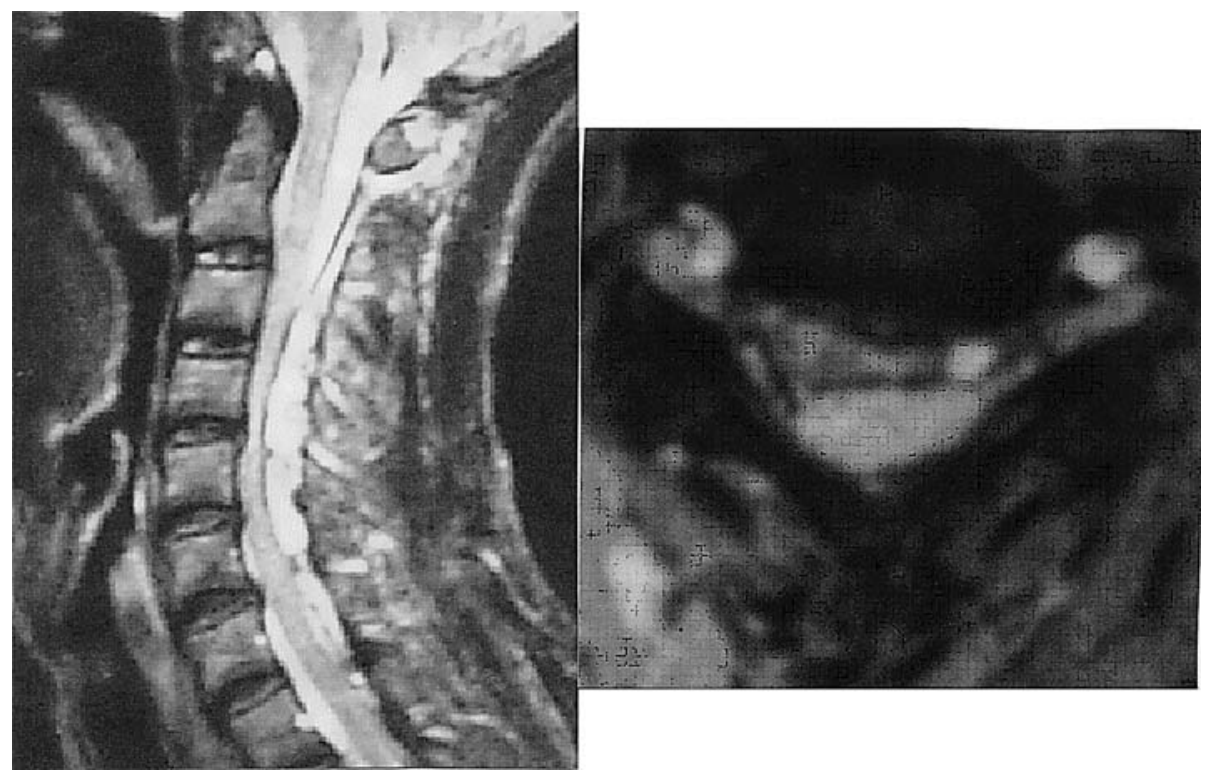

図 2 症例 3 発症後 7 時間 : T2 強調画像 $\mathrm{C} 3-\mathrm{C} 7$ レベル硬膜外背側に位置する $\mathrm{T} 1$ 強 調像で等信号, T2 強調像で高信号の血腫を認めた。

射消失認めた。基礎疾患として慢性腎不全にて HD と，DM 内服中であった。 頚椎 MRI にて C2-Th2 レベル硬膜外背側に位置する $\mathrm{T} 1$ 強調像で等信号， T2 強調像で高信号の血腫を認めた。発症後 18 時間にて 症状改善傾向なく, 手術（血腫除去術，C3-C7 椎弓 形成術）を行った。術後 2 日で症状改善あり。術後 1 年 10 ケ月で左上下肢の知覚障害, 筋力低下 (MMT 4) 残存した.

$$
\text { 考察 }
$$

脊骾硬膜外血腫は外傷，脊椎手術，腰椎穿刺などに よる二次性と，原因を特定できない（軽微な外傷を含 む）特発性に大別され，40～50\% は特発性であると されている，特発性脊髄硬膜外血腫（SSEH）は中年 以降に好発し，好発部位は下部頚髄〜上部胸䯣と下部 胸髄〜上部腰髄であり，発症様式として急激な背部痛 と続発する四肢麻痺が特徵的で，早期診断と適切な治 療が重要とされている. SSEH の MRI 所見は硬膜外 腔に紡錘形の腫瘤として血腫を認め，信号強度は発症 からの時期により異なる. 急性期では T1 強調画像に て脊髄と等信号, T2 強調画像にて不均一な高信号, 造影 MRI では中心部に造影されない. SSEH の治療
方針は早期の血腫除去術が推奨され，術後成績を左右 する因子として発症〜手術までの時間と術前の麻痺程 度が指摘されているが，手術時期については 6 時間以 内， 12 時間以内， 24 時間以内，48 時間以内と一定の 見解はない. また，自然回復例の報告については近年 では増加しており，田中ら ${ }^{4)}$ は自然回復例の特徵とし て麻痺が軽度（MMT 3 以上），麻痺の回復が 24 時間 以内に始まる，完全麻痺でも 6 時間以内に麻痺の改善 傾向があるとしている.

頚椎発症の SSEH については, 胸椎発症と比較し, 頚椎発症では治療成績が良好な症例の割合が高いとさ れている，一方で，成績不良例も散見されるが，具体 的な治療方針はない. 1996 年の Groen らの 330 例の SSEH の手術症例について報告 ${ }^{2)}$ を調査すると, 102 例の頚椎発症の SSEH では術前の麻痺が Frankel A であれば治療成績は劣る。また，術前 Frankel A の 症例では発症後 12 時間以内であれば，治療成績の悪 化を防げる可能性がある。さらに, 術前の麻痺が Frankel B 以上であれば，発症後手術に至る時間が 6 時間以内， $6 \sim 12$ 時間以内， $12 \sim 24$ 時間以内， 1 日以 上と時間が経過するにつれ，成績不良の割合も少しず つ増加する傾向にあることがわかつた．また，2004 


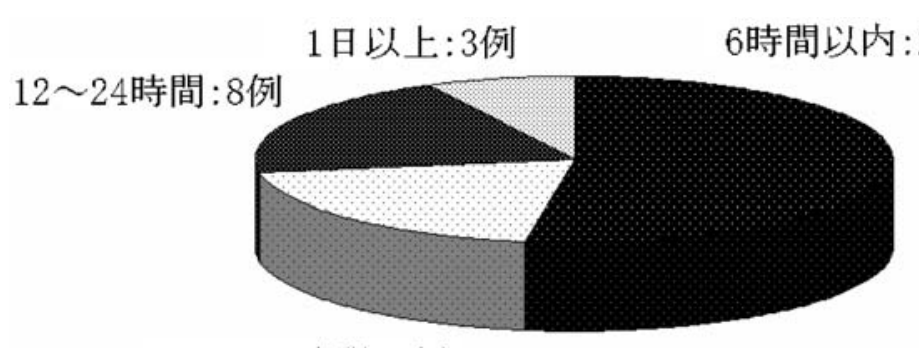

\section{$6 \sim 12$ 時間: 8例}

図 3 頝椎発症の SSEH の自然回復例（過去の国内報告と自験例） 40 例： 発症から麻痺の改善傾向出現までの時間

年の Groen の 64 例の SSEH の非手術症例について 報告 ${ }^{1)}$ では, 保存例では頝椎の占める割合が多いこと がわかる.また，頚椎発症の SSEH の自然回復例に ついて，過去の国内報告と自験例とをあわせた 40 例 の発症から麻痺の改善傾向出現までの時間を調査する と（図 3), 小久保らの報告 ${ }^{3)}$ ( $\mathrm{SSEH}$ の自然回復例 : 全脊椎発症 43 例) と比較して, 頚椎発症では 6 時間 以内に改善傾向を示す割合が高いことがわかった．以 上より, 頚椎発症の $\mathrm{SSEH}$ の治療方針（当院の方針） は麻痺の程度を考慮し, 緊急手術の準備を進めながら 経過を見て, 症状改善傾向が無い時には手術を行う. 特に，6時間までは自然回復を期待し，12 時間以内で の手術を検討するとしている.
結語

頚椎に生じた特発性脊髄硬膜外血腫は, 手術を検討 しながら, 注意深く症状経過を観察する必要がある.

\section{参 考 文 献}

1) Groen, R. J.: Non-operative treatment of spontaneous spinal epidural hematomas: a review of the literature and a comparion with operative cases. Acta Neurochir. (Wien), $146:$ 103-110, 2004.

2) Groen, R. J., van Alphen, H. A.: Operative treatment of spontaneous spinal epidural hematomas: a study of the factors determining postoperative outcome. Neurosurgery, 39 : 494-508, 1996.

3）小久保吉恭ら：春髄硬膜外血腫の治療方針．東日本整 災会誌, $17 ： 113-118,2005$.

4）田中雅人ら：保存的治療にて軽快した脊髄硬膜外血腫 の 1 例. 整形外科, $46: 1525-1527,1995$. 